\title{
Using the Interactive White Board in Teaching and Learning - An Evaluation of the SMART CLASSROOM Pilot Project
}

\author{
Edith Manny-Ikan \\ Henrietta Szold Institute, \\ Israel \\ edithmi@szold.org.il
}

\author{
Osnat Dagan \\ KadimaMada Educating for Life, \\ Israel \\ osnat.dagan@kadimamada.org
}

\section{Tal Berger Tikochinski and Rachel Zorman Henrietta Szold Institute, Israel}

\author{
tal@szold.org.il; rachelz@szold.org.il
}

\begin{abstract}
In 2008, an educational organization that works in 60 countries across the world, established a pilot project whereby smart classrooms were installed for use in six middle and senior high schools in Israel. In this project, each school received 10 Interactive White Boards (IWBs) (25\% of the total number of classrooms in the school), 32 laptops, internet connection, communication software and teacher training. Formative evaluation accompanied the pilot project for two years in order to examine the effects of integrating technology into instruction on teachers, students, and the school community.

The findings indicated the following: a) student motivation and engagement in the learning process increased when studying with the IWB; $b$ ) teachers reported on their professional development and enhanced technology skills. The findings also showed that the integration of technology into instruction posed some difficulties and challenges, such as a sense of over-burdening among teachers. The main conclusions were the following: a) there is a need to focus on the pedagogical training of the teachers, with an emphasis on the ways that technology can assist interactive teaching; b) in order to help relieve the over-burdening of teachers, a database of instructional tools should be established providing suggestions for lesson plans and instructional materials; c) accessibility to the technology should be extended to more teachers and students by adding smart classrooms to every school in the project.
\end{abstract}

Material published as part of this publication, either on-line or in print, is copyrighted by the Informing Science Institute. Permission to make digital or paper copy of part or all of these works for personal or classroom use is granted without fee provided that the copies are not made or distributed for profit or commercial advantage AND that copies 1) bear this notice in full and 2) give the full citation on the first page. It is permissible to abstract these works so long as credit is given. To copy in all other cases or to republish or to post on a server or to redistribute to lists requires specific permission and payment of a fee. Contact HPublisher@InformingScience.orgH to request redistribution permission.
Keywords: Interactive White Board (IWB), ICT, interactive learning, technology in education

\section{Introduction}

This article describes an evaluation research conducted in Israel, which examined different aspects of the contribution of the Interactive White Board (IWB) technology to learning and teaching

\section{Editor: Alex Koohang}

An earlier, shorter version of this paper was presented at the Chais conference 2011, in Raanana, Israel, and included in Y. Eshet-Alkalai, A. Caspi, S. Eden, N. Geri, \& Y. Yair (Eds.), Proceedings of the Chais conference on instructional technologies research 2011: Learning in the technological era. Raanana: The Open University of Israel. http://www.openu.ac.il/research center/chais2011/papers.html 
processes. The research was conducted on a pilot project of six schools (4 in the north and 2 in the south of Israel) which implemented the SMART project. This project was planned and executed by an international, Jewish education organization that works worldwide in 60 countries to enhance technology and science education. In Israel, this organization enhances science and technology education and also integrates advanced technologies in education. Project "SMART" was developed by this organization in order to enhance teaching and learning processes by using information and communication technology (ICT). Smart classrooms were built in various schools in Israel. The smart classroom consists of an electronic whiteboard that enables interaction, writing, and surfing the Internet using didactic software that accompanies the board. The organization funded the smart classrooms and provided in-service teacher training in cooperation with the Ministry of Education in Israel. It should be noted that this project wasn't centralized. No curriculum materials or learning objects were developed and delivered to the schools. All of the curriculum materials were developed locally by the teachers or groups of teachers, as part of the funding organizations' view that stresses that it is important to regard teachers as professionals who know their subject areas and enable them to develop materials independently. Thus, materials were developed in various subjects such as: mathematics, English as second language, geography, history, sciences, bible, civic studies, etc.

The findings presented in this article are those that primarily relate to the integration of the IWBs in instruction and learning, as this is the primary technological tool that the teachers began using. This study is unique in examining different models of implementing IWB in schools in Israel. These include using IWB in homerooms, in laboratories, or in both. Moreover, it examines how these models are related to the number of hours that students learn in classrooms using IWB and to teacher skills in using IWB.

\section{Background - Use of Interactive White Boards (IWBs)}

The use of IWBs integrates the functions of a regular board with additional means that enable interactive and constructivist learning and teaching (Betcher \& Lee, 2009; Way, Lifley, Ruster, Johnco, Mauric, \& Ochs, 2009). The IWB is a technology made up of a computer connected to both a projector and a touch-sensitive board that presents the pictures projected from the computer, allows for changes, and receives input electronically or by touch. The software for the IWBs allows a range of activities, including those that can be used without the use of the IWB (e.g., projecting presentations and short films, writing, and erasing the board) as well as activities unique to this technology. For example:

1. Drag and drop: an item on the board that can move in various directions.

2. Hide and reveal: an item located on top of others can be removed.

3. Highlighting: a clear color that can be placed on top of writing.

4. Animation: Items can be spun, change size, and move in a pre-determined direction.

5. Storage and recall: Unlimited storage and quick recall of material.

6. Feedback: When touching a particular item, there is visual or auditory feedback (Glover, Miller, Averis, \& Door, 2005).

With the spread of IWBs in various countries (United States, Mexico, Italy, Britain, Australia) its impact on aspects relating to teachers and to learners (among others) has been examined. 


\section{Learner Perspectives}

\section{A. Attitudes towards Learning}

Numerous studies have shown that use of IWBs improves learning processes, specifically where the integration between the teacher's instruction style and the IWBs' potential enables meaningful instruction (Betcher \& Lee, 2009). Students reported that the use of the IWB enhances motivation to learn, raises the level of concentration, improves behavior, and enhances learning because it is "fun" and innovative (BECTA, 2008; Cogill, 2002; Hall \& Higgins, 2005; Levy, 2002; Morgan, 2008; Thompson \& Flecknoe, 2003). Various studies have shown that students who learned with the IWB were more attentive and engaged in learning, participated more actively in the classroom, and interacted much more with their teachers, their peers, and even with the IWB (Higgins, Beauchamp, \& Miller, 2007; Miller, Glover, \& Avris, 2004; H. Smith, Higgins, Wall, \& Miller, 2005). Additional studies provided evidence that the IWBs serve as significant motivational tools for students, and facilitate students' desire to remain on-task (Cooper, 2003; Levy, 2002). Students' criticisms regarding the use of the IWBs were that there are sometimes technical problems, that it is difficult to see the boards from a distance, and that the teachers are not skilled enough in their use of the IWB (Hall \& Higgins, 2005).

\section{B. Developing $21^{\text {st }}$ Century Thinking and Learning Skills}

An expected long-term outcome of smart classrooms in general and IWBs in particular, is their use to develop thinking and learning skills that are appropriate for the $21^{\text {st }}$ century. As Melamed and Salant (2010) note in their literature review on the topic of integrating technology into educational systems around the world, " The school, part of whose task is to prepare the younger generation for the future, needs to recognize the world of these young children today and to know what will be required of them as they grow up. Among its responsibilities, the school has to develop in its students the skills that will be required of them in order to succeed to cope with the challenges that await them as they grow up" (p. 6). Instructors, researchers, professionals, teachers, and students all raise the question: What are the skills that will be needed by the graduates of the educational system in the $21^{\text {st }}$ century?

In order to answer this question, Melamed and Salant (2010) summarized the findings of organizations, researchers, and educational experts (including: Learning \& Technology World Forum, NCTE, Expert 21, Partnership for $21^{\text {st }}$ Century Skills) and created a list of the most important skills in the literature that they examined.

The five central skills were as follows:

1. Information skills (literacy): Skills that relate to the ability to gather, edit, analyze, process, and connect information.

2. Higher order thinking skills: In particular, problem solving, critical thinking, and creative and entrepreneurial thinking.

3. Communication and cooperation skills: The ability to work in a team, and to belong to various communities.

4. Skills to use technological tools, despite the feeling that young people know how to do this.

5. Learning skills: In particular, the development of autonomous learning.

In this context, the question must be raised as to whether learning in smart classrooms can contribute to the development of $21^{\text {st }}$ century skills, and what is the role of the IWB in this process. Findings of various studies demonstrated that various aspects of learning with an IWB can con- 
tribute to the development of these skills. For example, there are reports that learning with the IWB helps develop autonomous learning, by means of developing a sense of self competence (Somekh et al., 2006; Walker, 2003). Additional studies found that skilled teachers create knowledge together with students in a dynamic process during the lesson as they develop ideas and speculations and engage in critical thinking and joint ownership of the knowledge (Hennessy, Deaney, Ruthven, \& Winterbottom, 2007). In this manner, the IWB may serve as a type of alternative to the teacher as the center of attention and may enhance cooperative learning in the class, contributing to the development of autonomous learning and higher order thinking skills.

Similarly, the use of IWBs may enable the immediate collection and analysis of student work in ways not previously possible (Moss, Jewitt, Levacic, Armstrong, Cardini, \& Castle, 2007), and as such, can contribute to communication skills and cooperation. Learning via the IWB is a modern methodology that allows teachers to bring various perspectives from the outside world into the classroom, through the formation of an authentic and more relevant connection to their students (Somekh et al., 2006).

In contrast to the above, other studies indicated that the use of IWBs can be perceived as an expression of local innovation (Levy, 2002) that is manifested as a short-term "Halo Effect," that does not allow for the use of the IWB as a medium for developing higher thinking skills (BECTA, 2008). As such, efforts should be directed to maintaining and cultivating innovative pedagogy integrated with technology, enabling students to develop thinking and learning skills corresponding to those expected of them in the $21^{\text {st }}$ century.

\section{The Relationship between Use of IWBs and Student Achievement}

Studies that have examined the relationship between the use of IWBs and student achievement have yielded mixed findings (Higgins et al., 2005; Lewis, 2003, Swan, Schenker, \& Kratcoski, 2008). Firstly, it seems that IWBs positively influenced students' ability to understand complex concepts, for example, in math and science (Hennessey et al., 2007; Mildenhall, Swan, Northcote, \& Marshall, 2008). Similarly, teachers contended that the multi-faceted technological presentation (that relates to a number of senses - sight, hearing, and sometimes even touch, when the student nears the board) aids students who have difficulty developing mental images of complicated concepts (Kennewell, 2006).

The contribution to student achievement was evident in a study in the United States by Zittle (2004), who examined the influence of lessons with the IWB on elementary school students' achievements in geometry. The study compared pre and post test scores of 53 students who learned with the IWB in comparison to 39 students who learned without the IWB. Significant statistical differences were reported between the groups' achievements, such that the group that learned with the IWB achieved higher scores. Similarly, Dhindsa and Emran (2006) compared differences between pre and post tests of college students who spent six chemistry lessons learning either with or without an IWB. In this study as well, statistically significant differences were found between the groups, in favor of the group that learned with the IWB. The positive influence of IWBs has also been found in the areas of math and language in elementary schools in the United States (Swan et al., 2008), as well as in achievement in literacy, math, and science by elementary school students in England (Lewin, Somekh, \& Stephen, 2008). It is important to point out that in this study, differences emerged in the use of the IWB between teachers who were more experienced using it and teachers who lacked such experience. According to the experienced teachers, the IWB became integrated into their pedagogy as a mediator of their interactions with the student, among the students themselves, and between the students and the IWB as part of the pedagogical changes taking place. After two years, skilled teachers learned to use the board for learning in pairs and in small group of three students. The researchers concluded that students feel 
greater motivation to demonstrate their capability and their knowledge in the operation of the various functions of the board, especially in small groups or individually, and the experienced teachers who identified this motivation used it to enhance student learning (Lewin et al., 2008).

Similar findings were obtained in a study by Lewin et al. (2008), where they found a positive correlation between British elementary school students' achievements in language and math and the length of time learning with the IWBs. At the beginning of IWB use the average and stronger students attained the highest scores, yet after two years all of the students improved in their achievement on national tests. Similar data was obtained regarding improved scores on national tests in Australia (Lee \& Boyle, 2004).

The relationship between the use of the IWB and student achievement is gaining interest in Israel as well. Results of a local study conducted by a middle school science teacher were posted on a blog of the website of the southern district of Israel. This teacher taught the topic of "the cell" in four classes, two of which learned with the aid of an IWB and two did not. Students' achievements were examined via a test constructed by the supervisor, which resulted in scores an average of 11 points higher by the students who learned in the IWB group over the students who did not. Further analysis of the data showed that it was primarily the students who were failing who improved in the direction towards average achievements (Elharr, 2010).

Despite these positive findings, it seems that the influence of the IWB on achievement is not unidirectional: Higgins et al (2005), who examined the implementation of the IWB in $5^{\text {th }}$ and $6^{\text {th }}$ grades in various areas of Australia, found that although students learning with the IWB showed statistically greater achievement on national tests in math and language in 2003, the difference was small and did not repeat itself on similar tests administered in 2004. An in-depth analysis of the data shows that the use of the IWB contributed primarily to the achievement of students who were weak in the area of language, particularly in the area of writing. In a comparative study conducted by Christophy and Wattson (2007), a group of high school students who learned abstract terms in chemistry with the use of the IWB actually received lower scores on a multiple choice test of knowledge in comparison to the group that learned traditionally (without the IWB).

Regarding the issue of the suitability of IWB to different populations of students, teachers posit that there is an advantage to the use of IWB's in elementary schools, and particularly with students with a learning disability (Bell, 2002; Goodison, 2002).

\section{Teacher Perspectives}

\section{A. Teachers' Attitudes toward Working with IWBs}

Various studies have found positive teacher attitudes towards working with IWBs. Moss et al (2007) found that teachers feel that working with IWBs makes them more up-to-date. Miller, Glover and Avris, (2005), who examined teacher attitudes in various studies, reported that teachers find working with IWBs relatively easy. While the preparation time for lessons is longer, the resulting value is worthwhile, that is, greater student motivation and concentration, support for various learning styles (visual and aural), materials that can easily be adapted for children of varying abilities, the preparation of a better lesson, and clearer presentation of learning material.

While reports by BECTA (2008) did not find evidence of pedagogical change among teachers who used IWBs, other studies showed that the use of the boards improved teachers' confidence, particularly in using technological skills. The greatest contribution was found in places where the teachers had IWBs and a laptop and received training and guidance to use the technology in ways that support pedagogical principles (BECTA, 2008; Betcher \& Lee, 2009; Birch, 2003; Higgins et al., 2005; Miller et al., 2005; Ofsted report, 2002; Underwood et al, 2004). 
It was further found that a lack of digital learning materials along with the amount of time needed by the teachers to prepare lesson plans are the primary difficulties cited by teachers. Despite the numerous hours invested in the development of learning materials for the IWB, teachers noted that the use of the IWB allows them to prepare comprehensible lesson plans with a variety of creative options, thus contributing to the enjoyment from instruction and to meaningful changes from the traditional instructional methods (Bennet \& Lockyer, 2008; Lee \& Boyle, 2004; Levy, 2002; Solvie, 2004).

There are those who contend that the introduction of the IWB is a "step backward" because it provides technological support to frontal learning (Lewis, 2003; Somekh et al., 2005). However, in longitudinal studies, it was found that along with an increase in frontal learning, there were also increases in class interactivity, in teacher-student dialogue, and amongst the students themselves (Lewin et al., 2008; Smith et al., 2005).

\section{B. Developmental Typology of Teachers Using IWBs}

The use of the IWB for instruction can serve as a catalyst for the change from traditional instructional methods to interactive and constructivist methods. This technology helps teachers use instructional methods in more up to date ways, and utilizes various media - such as text, voice, pictures, and movies - that facilitate more effective learning, even in routine practice activities (ERNIST, 2004).

In the study by Lewin et al. (2008) on the influence of the use of IWBs on learning and instruction in English elementary schools, the authors defined and characterized stages of pedagogical change that take place with teachers after two years of working with the IWB:

1. First stage: Teachers match the new technology to existing pedagogy.

2. Second stage: Teachers are involved with discovering new opportunities offered by these technologies.

3. Third stage: Skilled teachers use the IWB in a professional and intuitive manner, which broaden or change their traditional pedagogy.

Similarly, Burden (2002) proposed a 3-stage model of use with the IWB:

1. Infusion: The intent here is for the broader usage of this technology, such that the technology strengthens the existing instruction, primarily as a didactic tool, while learning is still mainly passive.

2. Integration: When the technology is integrated into the school and into the curriculum, providing support to attaining the instructional goals in various subjects. Attention is also paid to ways to actively involve the students.

3. Transformation: When the use of the technology adds value to the whole learning process. The teachers use and create a variety of learning resources that strengthen inquirybased learning processes. The learners become centrally involved in the use of the IWB through the active building of knowledge via interaction.

Beauchamp (2004) and Somekh and Haldane (2005) also proposed models that describe the technological development of teachers via the relationship to the acquisition process of pedagogical practices using technology. Glover, Miller, Averis, and Door (2007) also developed a 3-stage model but focused on the change in interactions that occur in the classroom during lessons using the technology.

The central question that arises surrounding the above linear models is whether they describe a process that should be similar in all schools and whether all teachers eventually, after a certain 
Manny-Ikan, Dagan, Berger-Tikochinski, \& Zorman

amount of time has passed, reach the advanced stages. According to Rudd (2007), there is evidence that teachers today are still coming to terms with the adoption of the tool itself and, according to Burden's (2002) model, are at the Infusion stage, as they use the IWB primarily as a didactic tool within the teacher's control. Among other reasons, it seems that this is due to the fact that the pedagogical approach of the schools, and teachers themselves, does not always encourage interactive and cooperative learning and instruction in the classroom. As of yet, there is not enough research evidence to provide a definitive answer to the question of whether these linear models actually characterize reality in the classroom. Nonetheless, more and more researchers agree that the emphasis needs to be on developing pedagogically and less on developing technologically (Jewitt, Moss, \& Cardini, 2007), since recent research has clarified that teachers do not have to acquire higher technological skills in order to undergo pedagogical change (Lewin et al., 2008).

\section{Pedagogical Practices Using IWBs}

Integrating technology into learning in general and with the IWB in particular raises the question - does the IWB make the teacher more interactive? In defining the task of the teacher as a "learning moderator," the assumption is that the teacher will use fewer frontal instructional methods and will alter instruction to be more dynamic and interactive. Traditional instruction, according to Avni, Rotem and Ben-Chefer (2010), is primarily frontal, in the narrow meaning - a teacherdirected strategy that places identical learning tasks for all the students, whose answers are usually found in the text being learned, and where the time for responding is equal for all students without taking into account differences in ability, level, or pace of learners. In general, this approach views the teacher as the central authority, who is responsible for what goes on in class, and it is reasonable to expect that the students will develop a low level of personal responsibility for the learning and social processes.

In contrast, in interactive learning pupils' contributions are encouraged, expected, and extended (DfEE, 2001, p.8) In this context, Anderson and Garrison (1995) claim that the instruction method that is the most meaningful and produces the best results is when the knowledge is built in an active manner, using interaction in the social space.

F. Smith, Hardman, and Higgins (2006) imply that the use of IWBs can encourage this type of instruction when they describe the boards as "pedagogical tools for the advancement of interactive instruction for the entire class" (p. 443). Similarly, Wallace (2007) suggests that the IWBs allow more meaningful contact between learners and the content by simulation activities that are displayed in an accessible manner. The use of the boards adds a type of "theatrical tension" in the class and creates a more attractive learning environment. As a presentation tool, when used properly, the IWB suggests a dynamic, varied, multi-faceted, and expressive type of instruction, all while saving and retrieving information in a relatively simple manner, something that can potentially reduce the workload on teachers (Glover \& Miller, 2001), and allows students varied opportunities to learn complex concepts (Bell, 2002; H. Smith, 2001). Wenglinsky (2002) also claims that meaningful learning is an outcome of the interaction between the learners and the teachers when the two sides contribute to the interaction.

Evidence from studies by Gillen, Kleine-Staarman, Littleton, Mercer, and Twiner (2007) and Gillen, Littleton, Twiner, Staarman, and Mercer (2007) indicate that the IWB can serve as an effective tool to encourage interaction between the students and the learning material, using teaching methods that include presentation of material in various ways. Their view is that this was an option for teachers in the past, but the technology of the IWB enables teachers to vary the modes of their presentation in easier, faster, and more efficient ways. In research reports published by BECTA (2003), it is also reported that use of the IWB contributed to greater student engagement in learning and encouraged their participation in lessons. Based on the literature, engagement and 
participation constitute significant parts of interactivity (Shenton \& Pagett, 2007). F. Smith et al. (2006), who explored the influence of IWBs on interactions between teachers and students aged 7-11 during language lessons, found that while use of the IWBs led to a faster pace during the lesson and more open-ended questions, traditional instructional lessons were still used. Their conclusion was that the technology itself is not what leads to a fundamental change in traditional instruction. Gillen, Kleine-Staarman, et al. (2007) also noted that while the IWB indicates a pedagogy that is still focused on the teacher, there are a number of clear interactive advantages: the technology allows the teacher to prepare material ahead of time or to be built during the lesson before the class, to retrieve material in an immediate and fast manner to be presented during the lesson as needed, and to change items directly, together with the students during the presentation, so that strategic, multi-faceted instruction can be created (see also Kennewell, Tanner, Jones, \& Beauchamp, 2007).

At the same time, other research indicates that the entry of technology into the classroom is not sufficient to raise the level of interactivity in the class or to adopt a new pedagogy. Moss et al. (2007) note that, while the IWBs symbolize significant development that allows teachers to arrange and organize information and content in a more effective and efficient manner, this does not automatically promise improved instructional quality or an improved learning experience. In a study by Le Breuilly (2004) it was found that the interactivity in instruction in a smart classroom remains within the framework of the "electronic magic" of the board. According to her, the modern technology of the board allows the students and teachers to have a reciprocal and interactive relationship with the board. Higgins et al. (2007) expand this point in their emphasis that the subject and knowledge expertise of the teacher who is mediating the interaction with the students serves as the greatest determining factor in the meaningful integration of the IWBs. Research by Wood and Ashfield (2008) further illustrates this point in a study that examined the influence of the use of IWBs on creative learning and instruction in language and math. Their conclusion was that, while the unique characteristics offered by the IWB enable quality lessons to be conducted at a faster pace, this depends primarily on the expertise and professionalism of the teacher who is mediating the interaction, who capitalizes on the creative use and capabilities of the board for learning and instruction.

\section{Goals and Research Questions}

The central goal of this research was to examine the circles of influence of the project from various perspectives: students, teachers, and school. Based on this goal, the following research questions were derived:

1. Are there various types of implementation of the IWBs in each school? If so, what are they?

2. Will there be a change in the level of student engagement in learning? What kind of change?

3. Will there be a change in teachers' instructional processes? What kind of change?

\section{Methodology}

The research population included various groups participating in the project. The first group of participants was six principals of schools in which IWBs were implemented. The average tenure of these principals in their respective positions at the school was 16 years, with the most experienced holding the position for 25 years. Additional participants were six innovation leaders teachers whose job is to integrate new technologies into the school. The average number of years of experience for these teachers was 14 years, with two and a half years of experience using IWBs. Similarly, 12 teachers were sampled (two teachers from each of the six participating 
schools) who taught various subjects using the IWB. The average number of years of experience for these teachers is 20 years, with a wide range between 4 and 38 years, and an average of two years using the IWB.

In addition, students in grades 7-12 participated in the study (838 students responded to questionnaires at the beginning of the year, and 636 at the end of the year). At the beginning of the 20092010 school year approximately $59 \%$ of the students who responded were from middle school, and $41 \%$ from high school At the end of the year the relative percentage of responding students in middle school went up to $72 \%$, compared to the $28 \%$ of students from the high school.

Lastly, three pedagogical coordinators whose task was to implement the project in the various schools also participated in the study.

\section{Research Instruments}

The study included diverse research instruments for the various populations that participated. The following measures were included:

1. Principal Questionnaire: The principals were asked about the expected impact of the project on the school, the definition of success for the project, major difficulties, the place and task of the principal in the successful operation of the project, and parental reactions to the project.

2. Innovation Leader Questionnaire: These teachers were asked about their role in the project's operation, description and characterization of the instruction using the IWB, questions on the training given teachers who are using the IWB, the impact of the project on the school and the students, attitudes regarding learning and instruction with the boards, major difficulties, and advantages of the project.

3. Teacher Questionnaire: The questionnaire was given to teachers who use the IWB as well as to the innovation leaders. Respondents were asked to describe and characterize their instruction using the IWB, their attitudes toward the training they received for instructing via the IWB, their expectations regarding the place and task of the teacher and the students in a lesson that uses the IWB, the impact of the project on the school, advantages and major difficulties.

4. Online Student Attitude Questionnaire: An online student attitude questionnaire was administered at the end of the 2008-2009 school year and at the beginning and end of the 2009-2010 school year. The students were asked about their prior knowledge of computer use and their attitudes toward learning via the IWB - motivation to learn, interest in learning, relevance of the content, engagement in class discussions, group work, evaluation of achievements, and command of learning skills.

5. Student Focus Group: In each of the participating schools, two focus groups were organized (at the beginning and end of the 2009-2010 school year). In each group, approximately ten students participated. The students were asked about the differences between regular lessons versus lessons using the IWBs, motivation to learn, and interest and interaction with the teacher using the IWB.

6. Infrastructure Baseline Data: Chart of data on how the IWBs are used in schools. From each school, the following information was gathered - number of hours of learning per week, ranges of ages, and subjects studied.

7. Observations: 24 observations were conducted of the lessons using the IWB.

8. Pedagogical Coordinator Questionnaire: This questionnaire was administered to pedagogical coordinators. At the beginning of the study, interviews were conducted with pro- 
fessionals from the funding organization, and at the end of the study questionnaires were given to the pedagogical coordinators. The coordinators were asked how they see their task in the project, what the work model is for the project in each of the schools for which they are responsible, advantages and disadvantages in each model, and the expected impact of the project on students, teachers, and the school.

\section{Methods of Analysis}

A number of analyses were conducted on the various data gathered from the study measures: The quantitative data that were gathered from the attitude questionnaires were analyzed using the SPSS program, using various statistical procedures (such as averages, frequencies, factor analyses, and significance testing). The qualitative data that was gathered from interviews and focus groups were analyzed using content analysis, some with the Narralizer software program.

\section{Results}

Major findings from the research study are reported below.

\section{Implementation Models for the IWBs in Schools}

Schools were given the opportunity to choose the location for the IWBs, and they selected three primary methods: installation only in homeroom classes, installation only in laboratories, or a mixed model between the two (which will hereafter be referred to as the "integrated model"). From the data gathered from the schools, it seems that differences exist between these models relating to the use of the IWB. The number of weekly hours of learning ranged from an average of 17.5 hours to 29 hours, where the greater numbers of hours were reported in schools using the integrated model of IWB installation (Figure 1).

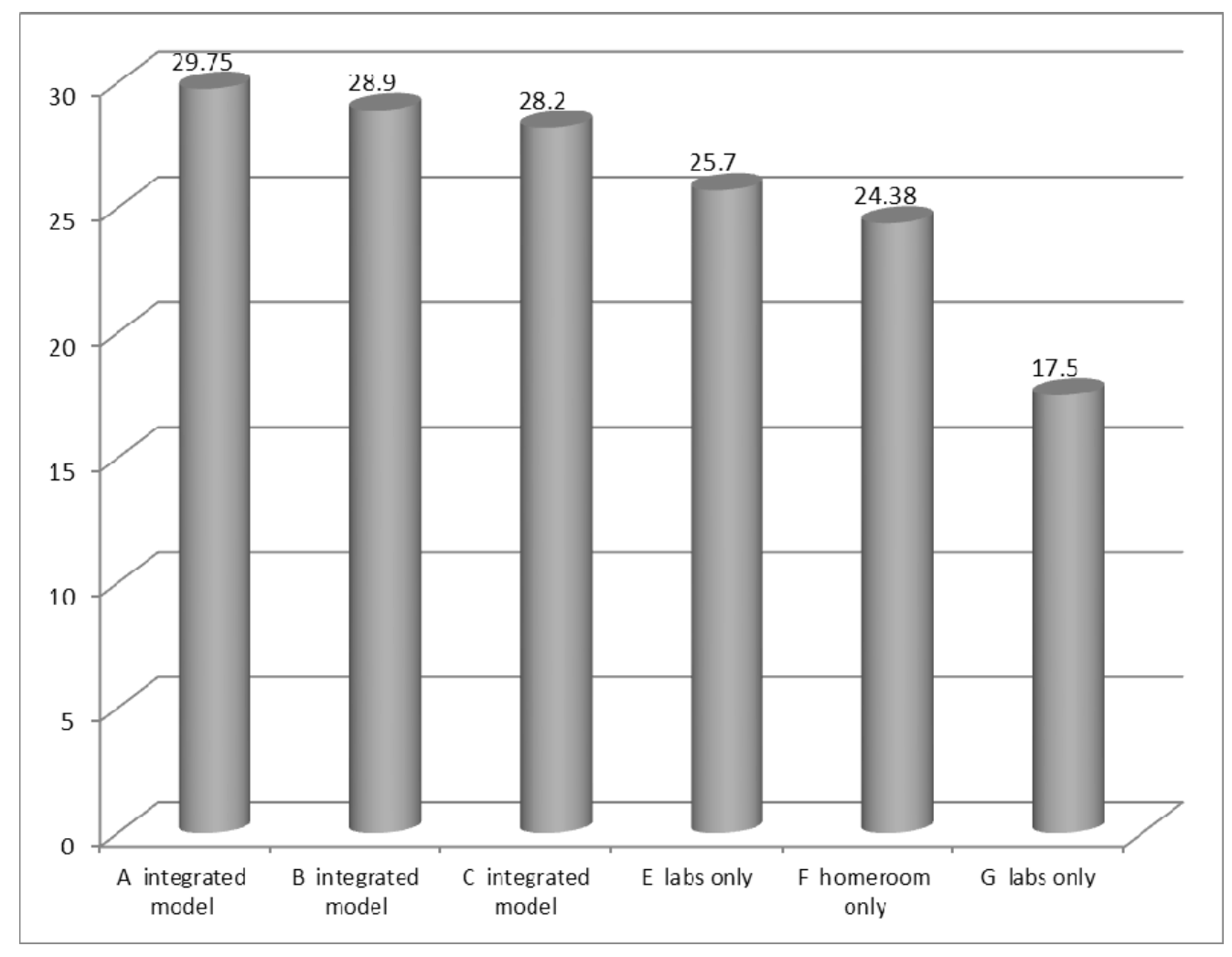

Figure 1. Average Weekly Hours of IWB Use in Schools 
Manny-Ikan, Dagan, Berger-Tikochinski, \& Zorman

\section{Attitudes toward the number of IWBs and their placement in the school}

The pedagogical coordinators, principals, and innovation leaders were asked their opinion on the best place for the IWBs - in homeroom classrooms or subject rooms (e.g. labs).

\section{a. Placement of the IWB in homeroom classrooms - advantages and disadvantages:}

Two principals and one innovation leader noted that the most efficient location for the IWB is in the homeroom class. The advantage of this implementation is that use of the IWB can then become more routine and continuous, and that teachers of other classes can utilize the boards when the homeroom class is learning in groups.

A possible disadvantage, noted by the pedagogical coordinators, is that there is exposure only to a small group of students, as the homeroom classes mainly serve one group of students. From the students in the focus groups, it seems that even when the IWB is installed in the homeroom class not all teachers make use of it. Thus, this resource is not fully utilized.

\section{b. Placement of the IWB in laboratories - advantages and disadvantages:}

According to one of the pedagogical coordinators, possible advantages to placement of the IWB in laboratories or in classrooms for specific departments (such as the science or language departments) is the preparation of the full array of lesson materials by the department staff, that is, cooperative thinking by a number of teachers who prepare the lessons, clear assignation of responsibility for maintaining the room, and the possibility of improvements to the room by the department staff (coordinator 3).

According to the coordinators, the disadvantages to this placement are the lack of utilization of the classrooms during the full weekly schedule and exposure of this technology to few students, as students tend to learn in these rooms in small groups. An additional disadvantage is that the other teachers do not use the IWB, and it becomes associated only with certain department, rather than all departments.

\section{c. Integrated Model:}

A portion of the principals $(n=2)$ and the innovation leaders $(n=3)$ recommend installing the IWBs both in homeroom classrooms as well as in classrooms for specific departments. The advantage cited by the innovation leaders to this placement is that in the homeroom class many teachers can use the IWB and can create a pace of learning with the IWB among the same group of students. Similarly, in classrooms for specific departments numerous groups of students use the space in a regular fashion.

\section{Student Perspective: Will there be a change in the level of student engagement in learning? What kind of change?}

\section{a. Students' attitudes toward learning via the IWB}

Based on student responses in the study, it seems that learning via the IWB is pleasurable, interesting, efficient, and comprehensible to the students, as can be seen in Table 1. 
Table 1: Students' Attitudes toward Learning via the IWB

\begin{tabular}{|l|c|c|c|}
\hline $\begin{array}{l}\text { In classes with an IWB, there is more than in traditional } \\
\text { classes... }\end{array}$ & $\mathbf{N}$ & Mean & $\begin{array}{c}\text { Standard Devia- } \\
\text { tion }\end{array}$ \\
\hline Enjoy learning & 620 & 3.79 & 1.21 \\
\hline Studies are interesting & 612 & 3.51 & 1.24 \\
\hline Can understand the learning materials & 616 & 3.43 & 1.22 \\
\hline Students want to participate in the lesson & 615 & 3.38 & 1.33 \\
\hline Studies are easier & 616 & 3.28 & 1.27 \\
\hline Students are more focused & 616 & 3.10 & 1.24 \\
\hline The teacher involves students in class discussions & 614 & 2.99 & 1.35 \\
\hline I like to come to school & 618 & 2.63 & 1.41 \\
\hline Students work in groups & 617 & 2.58 & 1.32 \\
\hline $\begin{array}{l}\text { The topics we learn are connected to my life and are relevant } \\
\text { to me }\end{array}$ & 617 & 2.43 & 1.29 \\
\hline Discipline problems & 616 & 1.91 & 1.21 \\
\hline The IWB distracts students from the lesson & 617 & 1.86 & 1.15 \\
\hline
\end{tabular}

Scale: 1- don’t agree, 2-agree a little, 3-agree somewhat, 4-mostly agree, 5-strongly agree

The following attitudes, among others, were also expressed by the students in the focus groups:

- Interest and Enjoyment: "She brings articles, short film, pictures . . . and it enriches the lesson and turns it into an interesting one" (School B); "It's interesting, because of the teacher and also because of the board, it depends on whether the teacher includes us" (School F).

- Comprehension: "The material is more comprehensible with the board, because the data is in front of your eyes, it doesn't pressure us, the brain is used to thinking like that" (School F); "If you miss something, you can come back to it. It's organized more clearly . .. I also think that there are simulations in science on the Internet, and these simulations help us understand" (School G).

- Efficiency: "Each time you used to have to take a ruler and start to draw and put in angles, but now, she just finds it, and it immediately corrects it to be exactly the way she wants. You can save a lot of time this way" (School E); "Everything is faster, and more organized. You get to the lesson, and everything is already ready" (School F).

\section{b. Student attitudes toward the influence of learning via the IWB on their educational achievements}

The majority of students, in all the participating schools state that their achievements in subjects learned via the IWB are similar to their achievements in other subjects learned traditionally. This finding was consistent both at the end of the 2008-2009 school year and at the beginning of the 2009-2010 school year (see Figure 2). 


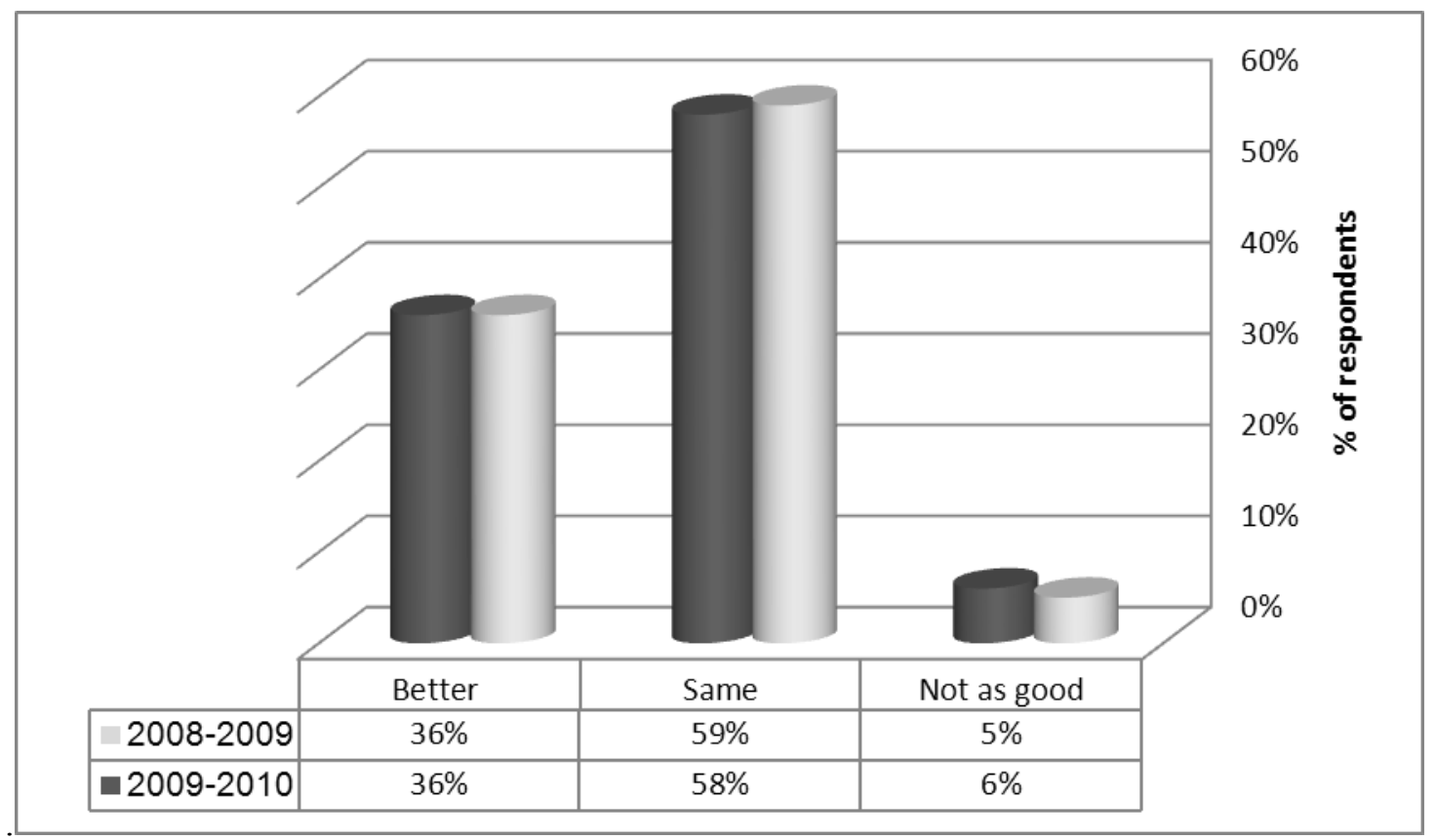

Figure 2: Student Assessment of Achievements in IWB vs. Traditional Lessons (among students in grades 7-12)

It is interesting to note that students in the focus groups pointed out that they don't necessarily see a connection between learning via the IWB and an improvement in their achievements. In contrast, two of the principals and eight of the teachers and innovation leaders expect that students' achievements will improve.

After two years of participation in the project, students were asked how interested they were in continuing in the following school year. Approximately $90 \%$ of the responding students $(n=560)$ want to continue in the project. A breakdown of responses according to school appears in Table 2.

Table 2: Students Who Want to Continue in Project SMART the Following Year

\begin{tabular}{|l|c|c|c|c|}
\hline School & Frequency & $\begin{array}{l}\text { Percent of Students Re- } \\
\text { sponding Affirmatively in } \\
\text { the 2008-2009 School Year }\end{array}$ & Frequency & $\begin{array}{l}\text { Percent of Students Re- } \\
\text { sponding Affirmatively in } \\
\text { the 2009-2010 School Year }\end{array}$ \\
\hline B & 155 & $99.4 \%$ & 175 & $97 \%$ \\
\hline F & 136 & $97.1 \%$ & 134 & $94 \%$ \\
\hline A & 142 & $94.0 \%$ & 70 & $85.4 \%$ \\
\hline E & 79 & $91.9 \%$ & 45 & $85 \%$ \\
\hline C & 88 & $88.0 \%$ & 51 & $76.1 \%$ \\
\hline G & 122 & $80.3 \%$ & 85 & $89.5 \%$ \\
\hline
\end{tabular}

It is important to note that, in the schools where student attitudes were more positive toward learning with the IWB, we found a correspondence between greater exposure of students to IWB 
(as assessed by the number of hours of learning in an IWB classroom) and reports by focus group students of greater skill by the teachers using the IWB.

\section{Teacher Perspective: Will there be a change in teachers' instructional processes? What kind of change?}

\section{a. Method of using the IWB}

Teachers were asked how they used the IWB during instruction. The primary uses for the IWBs reported by teachers are surfing the Internet $(n=17)$, projecting presentations $(n=17)$, and including the students in the lesson $(n=16)$. The least frequent use reported was listening to songs $(n=9)$.

\section{b. Teacher attitudes toward instruction using the IWB}

Teachers were presented with statements expressing attitudes toward use of the IWB during instruction and were asked to mark the extent to which they agree with each statement on a scale ranging from 1 (don't agree) to 5 (strongly agree). Their answers can be seen in Table 3 .

Table 3: Teacher Attitudes toward Instructing Using the IWB (n=18)

\begin{tabular}{|l|c|c|}
\hline Statement & Mean & $\begin{array}{l}\text { Standard Devia- } \\
\text { tion }\end{array}$ \\
\hline I enjoy teaching & 4.56 & 1.04 \\
\hline I need to invest a lot more work & 4.50 & 1.04 \\
\hline $\begin{array}{l}\text { I can more appropriately match the learning materials to the needs of } \\
\text { different students }\end{array}$ & 4.44 & .78 \\
\hline $\begin{array}{l}\text { I have better access to learning materials and resources at different } \\
\text { levels }\end{array}$ & 4.38 & 1.09 \\
\hline I can teach topics in greater depth & 4.35 & .70 \\
\hline I feel that my instruction is more professional & 4.22 & .94 \\
\hline I am open to more up-to-date materials & 4.18 & 1.07 \\
\hline I am strengthening my knowledge in the subject areas I teach & 4.07 & 1.03 \\
\hline I can more easily fulfill the learning goals & 4.00 & .84 \\
\hline I raise my expectations from students' work & 3.87 & 1.19 \\
\hline I feel that the students appreciate me more & 3.82 & 1.33 \\
\hline There are fewer discipline disturbances in the class & 3.61 & 1.04 \\
\hline I am more dominant and meaningful in the school & 3.47 & 1.36 \\
\hline
\end{tabular}

Scale: 1- don't agree, 2-agree a little, 3-agree somewhat, 4-mostly agree, 5-strongly agree

From Table 3, it appears that the statements that were most agreed with relate to the teachers enjoying teaching $(4.56$, s.d.=1.04) and that teaching with the IWB requires a greater investment of work $(4.50$, s.d. $=1.04)$. The statements that were least agreed with were that there were fewer discipline disturbances in class $(3.61$, s.d. $=10.04)$ and that the teachers do not necessarily feel more meaningful and dominant in the school $(3.47$, s.d.=1.36). The standard deviations illustrate that differences exist between the teachers. 
Based on this, teachers see the project's contribution to learning primarily in the use of up to date instructional tools that lead to greater variety, illustration, and motivation to learn. Instruction using the IWB is more enjoyable for teachers, but at the same time requires greater investment in planning lessons.

In addition to the above, teachers were also asked about their thoughts on the project's influence on their students' learning. Their answers are presented in Table 4.

Table 4: Teacher Attitude towards Instruction Using the IWB

\begin{tabular}{|l|c|c|}
\hline Statement & Mean & $\begin{array}{l}\text { Standard De- } \\
\text { viation }\end{array}$ \\
\hline Student interest level in the lesson & 2.83 & .51 \\
\hline I provide tools for the students that help them learn & 2.82 & .39 \\
\hline Students' level of participation in the lesson & 2.78 & .43 \\
\hline $\begin{array}{l}\text { During the lesson students present presentations that they have pre- } \\
\text { pared }\end{array}$ & 2.69 & .48 \\
\hline Level of students' concentration & 2.69 & .60 \\
\hline $\begin{array}{l}\text { I can guide the students' to reach answers to questions and assign- } \\
\text { ments on their own }\end{array}$ & 2.67 & .49 \\
\hline The students like the subjects being learned & 2.67 & .49 \\
\hline $\begin{array}{l}\text { I can ask the students to bring examples from their own lives that } \\
\text { relate to the material being learned }\end{array}$ & 2.56 & .51 \\
\hline I use examples that the students bring during the lesson & 2.44 & .51 \\
\hline I conduct discussions with the students & 2.44 & .51 \\
\hline How much effort the students invest in learning in the class & 2.39 & .70 \\
\hline The students are present during the lesson & 2.33 & .49 \\
\hline The investment students make in doing their homework & 2.17 & .38 \\
\hline The students work in groups & 1.94 & .64 \\
\hline The students are bored during the lesson & 1.33 & .59 \\
\hline
\end{tabular}

Scale: 1-Less than a traditional lesson, 2-no difference from a traditional lesson, 3-more than a traditional lesson

It appears that the teachers feel that use of the IWB improves their ability to provide skills and learning tools for the students, influences the levels of interest, concentration, and enjoyment of the subjects being learned, as well as students' participation in the lesson.

Teachers were asked about the training that they received on instruction using the IWB. Their answers to this question are presented in Table 5. 
Table 5: Teacher Attitudes toward Training in Instruction Using the IWB

\begin{tabular}{|l|c|c|}
\hline Teachers (N=18) & Mean & $\begin{array}{l}\text { Standard De- } \\
\text { viation }\end{array}$ \\
\hline I feel able to teach without training for the next school year & 4.46 & .78 \\
\hline $\begin{array}{l}\text { Following training, I know how to integrate between the IWB and } \\
\text { learning materials in my content area }\end{array}$ & 4.09 & .83 \\
\hline $\begin{array}{l}\text { The training contributed to my technological knowledge of operating } \\
\text { the IWB }\end{array}$ & 3.92 & 1.19 \\
\hline $\begin{array}{l}\text { The training contributed to my technological knowledge of my fa- } \\
\text { miliarity with the computer }\end{array}$ & 3.46 & 1.27 \\
\hline $\begin{array}{l}\text { Following the training, I can independently develop learning materials } \\
\text { for the IWB (digital learning units ) }\end{array}$ & 3.42 & 1.38 \\
\hline $\begin{array}{l}\text { The training contributed to my pedagogical knowledge in the content } \\
\text { area that I teach }\end{array}$ & 2.75 & 1.36 \\
\hline
\end{tabular}

Scale: 1-not at all, 2-a little, 3-somewhat, 4-mostly, 5-fully

It appears that teachers request additional professional development that includes pedagogical content, together with additional technological training, despite the fact that their overall feeling is that they can instruct without training.

\section{Major Difficulties and Challenges in the Project}

The primary difficulties that were noted in the study relate mostly to the following:

- Shortage of IWBs in the school (3 coordinators, 3 principals, 3 teachers, 2 innovation leaders): This shortage makes it difficult to create continuity in the learning throughout the school (2 principals).

- Pedagogical use of the IWB in a manner that takes advantage of their added value: According to the principals, after approximately six months of the project, the IWBs are being used regularly, the technical problems are resolved, and there is widespread use of the IWBs. The questions that they want to address at this stage are, "What is the "correct' usage of the IWB from a pedagogical standpoint," and particularly, "How to use the board to advance the learning beyond the initial 'attraction' of the technology" ( 2 principals, 2 teachers, 1 innovation leader).

- Technological difficulties operating the IWBs: At times there were technical and technological malfunctions in the operation of the IWBs (2 principals, 8 teachers). Despite this, the majority of principals and innovation leaders reported that there was access to technical support. From this perspective, it seems that there was a certain improvement in the reports of the innovation leaders from the end of 2009, when 4 coordinators reported that the technical support was not sufficient.

- Over-burdening of the teachers: Preparing lessons for instruction using the IWB takes a large amount of time (6 teachers, 2 innovation leaders); participation in significant professional development, in addition to the regular tasks and professional development that teachers already participate in, places additional burden on teachers ( 2 principals, 2 teachers). 


\section{Discussion}

The evaluation research that is reported in this article is an initial study of the entry of smart classrooms and IWBs into Israel and was conducted as a pilot with six schools for about two years. Findings from the study support research conducted internationally on the impact of implementing IWBs on learning and instruction.

\section{Student Perspective}

\section{a. Contribution to students' engagement in the lesson}

The findings of this study reveal that student attitudes toward learning with the IWB are predominantly positive. Aside from greater enjoyment of learning, students report on the contribution of the IWB to their learning process, particularly on greater understanding of the material, greater interest and engagement in the learning process that is also expressed in a desire to be active participants in the lessons. These findings are similar to findings from other studies, such as Hall and Higgins (2005), who found that students learning via the IWB are more attentive and have greater motivation to learn. In addition, Hall and Higgins pointed out that presenting learning material using multimedia clarifies the material and enhances learning. The teachers in the current study reported similar findings.

Despite these positive reports on the contribution of the IWB to student learning, other studies highlight that the increase in student engagement may only be short-term. In order to maintain their level of engagement and their interest in learning, instruction via the IWB needs to be more challenging than just demonstrating simple assignments on the board and needs to develop higher thinking skills among students. Otherwise, there is a risk that the learners will cease to be interested over time, and the technology will become outdated and useless (Lancia, 2009).

Similarly, in the current study, it is possible to see that in the second year, there was a slight decrease in students' positive attitudes relating to their desire to continue learning via the IWB. It is possible that this is due to the more routine use of the IWB and the lack of variety in how the teachers use it. As such, in order to continue to maintain the high level of student motivation, other methods for using the IWBs need to be explored.

\section{b. Developing $21^{\text {st }}$ century skills}

The development of $21^{\text {st }}$ century skills in students was not examined directly in this study. However, based on teacher and student reports, it is possible to see that various aspects of these skills are developed by instruction via the IWB in Project SMART. For example, the teachers note that instruction via IWBs allows them to provide their students with tools that will help them learn in a more effective manner than in a traditional lesson.

Among the central skills of the $21^{\text {st }}$ century noted by Melamed and Salant (2010) are learning skills that focus on the development of an autonomous learner. From the results of the current study it appears that learning via the IWB enhances the acquisition of this skill in a number of ways, especially by saving the learning materials and sending them to the students. The possibility of saving the development of the authentic lesson as it was conducted in class is unique to the IWB. This activity has two main advantages - first, by providing the opportunity for independent learning even beyond the regular class time and, secondly, by providing students with the opportunity for greater focus and concentration when learning on their own, since they are not occupied with summarizing the learning materials.

An additional contribution that comes up in the literature and is connected to the development of higher order thinking skills relates to the ability to better present the learning material, to provide 
clarifications and visual presentation, using models and explanations to teach complicated concepts, and by reports of greater concentration of students and more time spent focusing on their learning (Kennewell et al., 2007; H. Smith et al, 2005). All of these elements were apparent from reports of both teachers and students in the current study.

Another skill that is needed for the $21^{\text {st }}$ century is the ability to use digital tools. Based on teachers' reports in the study, it seems that they expect their students to be more able to prepare and present presentations during lessons. Preparing presentations requires students to use search tools, organize information, and learn how to present information visually in a succinct manner. In this way, students can gain experience with skills that develop their information literacy and learning processes, alongside actively practicing learning with digital tools not only for the purpose of playing games.

\section{c. The relationship between IWB use and attitudes toward achievement}

The results of our study indicate that the majority of teachers and innovation leaders and a portion of the principals think that learning via the IWB can positively influence student achievements.

On the other hand, less than one-third of students (36\%) feel that their achievements will improve following learning with the IWB, and a majority of them (58\%) feel that their achievements will remain the same.

It is interesting to note that the students report that they better understand the learning material, a characteristic that, according to Blau (2009), can serve as a possible explanation for the increase in the achievement of students learning with the IWB. An example of this appears in studies where the use of the boards' visual aids can improve understanding of concepts in math (Mildenhall et al., 2008) and in science (Hennessy et al., 2007). The study by Hennessy et al. (2007) on high school students learning with the IWB demonstrated that a better understanding of science concepts stems from the fact that students evaluated and developed scientific ideas on their own during the course of the lesson through the use of the interactive capabilities of the IWB.

The difference between the students' responses versus the teachers' and innovation leaders' assessments, raises the question of whether student attitudes stem from the fact that they are aware of the fact that the skills and methods of learning with the IWB are not always evident on standardized tests. While some of the teachers reported that their expectations from their students included digital work, such as presenting a presentation during the lesson, the high stakes tests that the students take are administered in a standard format. An example of this arises from the comparison study by Christophy and Wattson (2007), where a group of high school students who learned abstract concepts in chemistry using the IWB received lower scores on a multiple choice test of knowledge in comparison to a group that learned in the traditional manner. These findings indicate that students may have difficulty transferring what they learned via technology to a paper and pencil test.

An additional explanation for this phenomenon is that, at times, learning with technology in general, and with IWB in particular, can be seen as a game, whereas during times of pressure, the technology is put aside and teachers go back to the traditional "teaching to the test." This may lead to a disconnection between student attitudes toward learning via IWB and their scores on standardized tests. In regard to this issue, it is interesting to note studies by Higgins et al. (2005) and Hall and Higgins (2005) that found that interactive instruction is limited because of the emphasis and importance that is put on curriculum that is centered on standardized tests, which requires teachers to "teach to the test" so that students will succeed. In this situation, teachers often feel that they need to control class progress and cannot allow students to express their perspective, leading to a decrease in students interactions in the classroom. Moreover, Hennessy et al. 
Manny-Ikan, Dagan, Berger-Tikochinski, \& Zorman

(2007) also found that the daily pedagogical context of the teachers within the framework of the school system is not flexible and requires them to stick to the curriculum, tests, and evaluation, often reducing teachers' freedom to try various approaches and new technologies.

\section{Teacher Perspective}

\section{a. Teacher attitude towards use of the IWB}

The attitudes expressed by the teachers in this study are similar to those described in other research (Miller et al., 2005). The teachers report that despite the difficulty of dedicating more time to preparing lessons, the upside is greater student interest, motivation, and focus, support for different learning styles (aural and visual), materials that are more easily adapted to students with varying abilities, planning a better lesson, presenting the learning material more clearly, and a feeling that that teachers are more up-to-date. From the teachers' reports, it seems that instruction using the IWB is more professional and enables greater exposure to a wide variety of materials. In addition, the relatively widespread use of presentations that was reported by a majority of teachers demonstrates that teachers are reorganizing their teaching materials for use with digital materials, something that promises more updated instruction.

\section{b. Interactive teaching}

The findings of this study show that, at this stage of Project SMART, the teachers primarily use the new tools but still anchor them in a traditional work model. These findings, which are similar to other studies, demonstrate that instruction using the IWB occurs primarily in a full-class setting. Thus, for example, Hall and Higgins (2005) found that the use of the IWB primarily included whole-class games and joint Internet research. In other cases, it was reported that use of the IWB is rather superficial, for example, doing some kind of manipulation on items on the board only in response to students' request (Gillen, Littleton, et al., 2007).

Furthermore, it seems that teachers are at the stage of acquisition of technical skills of the IWB and use the IWB in order to enrich existing pedagogy (first stage of the model by Lewin et al., 2008 or that of Burden, 2002). It is apparent, from student testimonies as well, that in the lessons learned via the IWB there is no more group work or work in pairs than in a traditional lesson. Despite these reports, based on interviews with teachers, innovation leaders, principals, and project coordinators, there are some indications that some of them are on their way to the second stage and are trying to increase and deepen their pedagogical training. It is important to note that $\mathrm{F}$. Smith et al. (2006) claim that newer instructional methods that encourage greater reciprocation between students and teachers can only come to fruition if teachers will receive in-service training and support. Thus, teachers are expected to go through change and pedagogical development in order to utilize the hidden potential of the IWB to improve learning and instruction processes.

Based on the current study, a number of recommendations emerge:

- It is important to train teachers to utilize the technology for new pedagogical purposes.

- It may be helpful to establish a database of lessons and instructional materials that integrate various technological elements in order to ease the burden on teachers in preparing interactive lessons.

- Adding smart classrooms in the school (at least 50\% of the classrooms) may help create continuity in the innovative methods of learning and instruction for most of the students.

- It may be important to consider the integrated model of installing smart classrooms in both homeroom classes as well as in specific departments (such as science laboratories or 
From a research perspective, it is important to continue to examine the various uses of smart classrooms in general, and IWBs in particular, in order to clarify how teachers' usage of the boards develops - that is, how do they reflect pedagogical development. For example, some of the questions that may be investigated are:

- Do the teachers advance according to the typology of Lewin et al. (2008) or of Burden (2002)?

- Does their technological level improve?

- Is there a connection between technological skill and pedagogical change, and what is the nature of this connection?

- What is the role of teacher training on this issue?

- We see the importance of identifying and characterizing "smart lessons" as examples of optimal and effective use of the IWB: What are the conditions that allow for the creation of a lesson that has the interactive characteristics and high levels of student engagement and what conditions limit this?

- Do teachers change their traditional frontal approach and use innovative pedagogy?

- Do various technological methods help structure the knowledge with the learner?

- Is it possible to characterize a "successful" instructional model, and, if so, is it possible to replicate it for other teachers and subjects?

- What will happen over time to the achievement of students who participated in these "smart lessons"?

- It is also advisable to research the impact of the introduction of smart classrooms on the image of the school in the community.

In conclusion, the technology of the IWB in the smart classroom, which is being integrated in various places in the world as well as in Israel, carries the hope for meaningful pedagogical change in traditional classroom learning. Teachers, students, and educational professionals all over the world contend with complex questions with respect to the ability of the technology to serve as an effective impetus for the anticipated changes. At the same time, evidence is accumulating that with effective teacher training that emphasizes the importance of technology as a tool for pedagogical change and improvement, teachers can indeed use the IWB to work together with their students on developing thinking skills and abilities that will enable them to address the challenges of the $21^{\text {st }}$ century.

\section{References}

Anderson, T., \& Garrison, D. R. (1995). Critical thinking in distance education: Developing critical communities in an audio teleconference context. Higher Education, 29, 183-199.

Avni, E., Rotem, A., \& Ben Cehfer, A. (2010). The renaissance of frontal teaching with and without the $I W B$ [In Hebrew]. Retrieved from http://www.avrumrotem.com/BRPortalStorage/a/25/33/77INvANEIcVn.pdf

Beauchamp, G. (2004). Teacher use of the interactive whiteboard in primary schools: Towards an effective transition framework. Technology, Pedagogy and Education, 13(3), 327 - 348.

BECTA. (2003). What the research says about interactive whiteboards. Retrieved from http://becta.org.uk 
BECTA. (2008). Harnessing technology schools survey 2007: Analysis and key findings. Retrieved from http://partners.becta.org.uk/uploaddir/downloads/page documents/research/ht schools survey07 key findings.pdf

Bell, M. A. (2002). Why use an interactive whiteboard? A baker's dozen reasons! Teachers Net Gazette, $3(1)$.

Bennett, S., \& Lockyer, L. (2008). A study of teachers' integration of interactive whiteboards into four Australian primary school classrooms. Learning, Media \& Technology, 33(4), 289-300.

Betcher, C., \& Lee, M. (2009). The interactive whiteboard revolution - Teaching with IWBs. Victoria, Australia: ACER Press

Birch, J. (2003). Using an electronic whiteboard. Retrieved from http://www.bucksict.org.uk/Teacher\%20Resources/DownloadDocs/Curriculum/ Whiteboards.doc

Blau, I. (2009, October). Interactive whiteboard: Makeup or real beauty? [In Hebrew]. Poster presented at the 7th MEITAL National Conference on The Open Knowledge World, Shenkar College of Engineering and Design, Ramat-Gan, Israel.

Burden, K (2002). Learning from the bottom up - The contribution of school based practice and research in the effective use of interactive whiteboards for the FE/HESector. Discussion paper presented at LSDA, Making an Impact Regionally Conference, The Earth Centre, Doncaster. Retrieved from http://www.lsnlearning.org.uk

Christophy, E., \& Wattson, E. (2007). The effect of interactive whiteboards on student learning in the chemistry classroom. Retrieved from http://faculty.shaexcelsior.org

Cogill, J. (2002). How is the interactive whiteboard being used in the primary school and how does this affect teachers and teaching? Retrieved from www.virtuallearning.org.uk

Cooper, B. (2003). The significance of affective issues in successful learning with ICT for year one and two pupils and their teachers: The final outcomes of the ICT and the Whole Child Project. NIMIS and Whole Child Project, Leeds University, Leeds, UK.

DfEE. (2001). Key stage 3 national strategy: Framework for teaching mathematic. London, UK: DfEE

Dhindsa, H. S., \& Emran, S. H. (2006). Use of the interactive whiteboard in constructivist teaching for higher student achievement, Proceedings of the Second Annual Conference for the Middle East Teachers of Science, Mathematics, and Computing, (pp. 175-188). Abu Dhabi. Retrieved from http://citeseerx.ist.psu.edu/viewdoc/download?doi=10.1.1.100.2093\&rep=rep1\&type=pdf

Elharr, S. (2010). Improving student achievement in science with the interactivewhiteboard [In Hebrew]. Retrieved from http://merkazh.blogspot.com/2010/06/blog-post 1287.html

ERNIST. (2004). ICT school portraits. Retrieved from http://www.eun.org

Fisher, S. (2006). Using technology to prepare for future scientists (Master's thesis). Retrieved from http://soar.wichita.edu/dspace/bitstream/10057/565/3/t06104.pdf

Gillen, J., Kleine-Staarman, J., Littleton, K., Mercer, N., \& Twiner, A. (2007). A ‘learning revolution’? Investigating pedagogic practice around interactive whiteboards in British primary classrooms. Learning, Media and Technology, 32(3), 243-256.

Gillen, J., Littleton, K., Twiner, A., Staarman, J., \& Mercer, N. (2007). Using the interactive whiteboard to resource continuity and support multimodal teaching in a primary science classroom. Journal of Computer Assisted Learning, 24, 348-358.

Glover, D., \& Miller, D. (2001). Running with technology: The pedagogic impact of the large-scale introduction of interactive whiteboards in one secondary school. Journal of Information Technology for Teacher Education, 10 (3), 257-276

Glover, D., Miller, D., Averis, D., \& Door, V. (2005). The interactive whiteboard: A literature survey. Technology, Pedagogy and Education, 14(2), 155-170. 
Using the Interactive White Board in Teaching and Learning

Glover, D., Miller, D., Averis, D., \& Door, V. (2007). The evolution of an effective pedagogy for teachers using the interactive whiteboard in mathematics and modern languages: An empirical analysis from the secondary sector. Learning, Media and Technology, 32(1), 5-20

Goodison, T. (2002). Learning with ICT at primary level: Pupils' perceptions. Journal of Computer Assisted Learning, 18, 282-295.

Hall, I., \& Higgins, S. (2005). Primary school students' perceptions of interactive whiteboards. Journal of Computer Assisted Learning, 21, 102-117.

Hennessy, S., Deaney, R., Ruthven, K., \& Winterbottom, M. (2007). Pedagogical strategies for using the interactive whiteboard to foster learner participation in school science. Learning, Media \& Technology, 32(3), 283-301. Retrieved from http://www.educ.cam.ac.uk/research/projects/istl/LMT_IWB.doc

Higgins, S., Beauchamp, G., \& Miller, D. (2007). Reviewing the literature on interactive whiteboards. Learning Media and Technology, 32(3), 213-225.

Higgins, S., Falzon, C., Hall, I., Moseley, D., Smith, F., Smith, H., \& Wall, K. (2005). Embedding ICT in the literacy and numeracy strategies. Newcastle, UK: University of Newcastle on Tyne.

Jewitt, C., Moss, G., \& Cardini, A. (2007). Pace, interactivity and multimodality in teachers' design of texts for interactive whiteboards in the secondary school classroom. Learning, Media and Technology, 32(3), 303-317.

Kennewell, S. (2006). Reflections on the interactive whiteboard phenomenon: A synthesis of research from the UK Swansea School of Education. Retrieved from http://www.aare.edu.au/06pap/ken06138.pdf

Kennewell, S., Tanner, H., Jones, S., \& Beauchamp, G. (2007). Analyzing the use of interactive technology to implement interactive teaching. Journal of Computer Assisted Learning, 24(1), 61-73.

Lacina, J. (2009). Interactive whiteboards: Creating higher-level, technological thinkers? Childhood Education, 85(4), 270-275.

Le Breuilly, M. (2004) Benefits of the interactive whiteboard. Primary English Magazine, 9(5), 25-28.

Lee, B., \& Boyle, M. (2004). Teachers tell their story: Interactive whiteboards at Richardson Primary School. Retrieved from http://education.smarttech.com

Levy, P. (2002). Interactive whiteboards in learning and teaching in two Sheffield schools: A developmental study. Retrieved from http://dis.shef.ac.uk/eirg/projects/wboards.html

Lewin, C., Somekh, B., \& Stephen, S. (2008). Embedding interactive whiteboards in teaching and learning: The process of change in pedagogic practice. Education and Information Technologies, 13(4), 291303.

Lewis, H. (2003). Using an interactive whiteboard in the daily mathematics lesson: Implications for teaching and learning. UWIC Education Papers, 2, 41-52.

Melamed, U., \& Salant, A. (2010). Integrating ICT into educational systems around the world [In Hebrew]. Retrieved from http://portal.macam.ac.il/ArticlePage.aspx?id=3194\&referer=useJsHistoryBack

Mildenhall, P., Swan, P., Northcote, M., \& Marshall, L. (2008). Virtual manipulatives on the interactive whiteboard: A preliminary investigation. Australian Mathematics Teacher 64(1), 9-14.

Miller, D., Glover, D., \& Avris, D. (2004). Matching technology and pedagogy in teaching mathematics: Understanding fractions using a 'Virtual Manipulative' fraction wall. Manchester, UK: British Educational Research Association. Retrieved from http://www.keele.ac.uk

Miller, D., Glover, D., \& Avris, D. (2005). Developing pedagogic skills for the use of the interactive whiteboard in mathematics. Staffordshire, UK: University of Keele, Department of Education. Retrieved from http://www.keele.ac.uk

Morgan, G. L. (2008). Improving student engagement: Use of the interactive whiteboard as an instructional tool to improve engagement and behavior in the junior high school classroom (Doctoral dissertation, Liberty University). Retrieved from http://digitalcommons.liberty.edu 
Moss, G., Jewitt, C., Levacic, R., Armstrong, V., Cardini, A., \& Castle, F. (2007). The interactive whiteboards, pedagogy and pupil performance evaluation: An evaluation of the schools whiteboard expansion (SWE) Project: London Challenge (Research Report No 816). London, UK: University of London, Institute of Education, School of Educational Foundations and Policy Studies. Retrieved from http://www.desf.gov.uk

Ofsted report. (2002). ICT in schools: Effect of government initiatives implementation in primary schools and effect on literacy (Report from the Office of Her Majesty's Chief Inspector of Schools). Retrieved from http://www.ofsted.gov.uk

Rudd, T. (2007) Interactive whiteboards in the classroom. Futurelab. Retrieved from http://www.futurelab.org.uk/resources/documents/other/whiteboards_report.pdf

Shenton, A., \& Pagett, L. (2007). From 'bored' to screen: The use of the interactive whiteboard for literacy in six primary classrooms. Literacy, 41(3), 129-136.

Smith, F., Hardman, F., \& Higgins, S. (2006). The impact of interactive whiteboards on teacher-pupil interaction in the national literacy and numeracy strategies. British Educational Research Journal, 32(3), 443-457.

Smith, H. (2001). Smartboard evaluation (Final Report). Retrieved from www.kented.org.uk

Smith, H., Higgins, S., Wall, K., \& Miller, J. (2005). Interactive whiteboard: Boon or bandwagon? A critical review of the literature. Journal of Computer Assisted Learning, 21, 91-101.

Solvie, P. (2004). The digital whiteboard: A tool in early literacy instruction. The Reading Teacher, 57(5), 484-487. Retrieved from http://www.readingonline.org

Somekh, B., \& Haldane, M. (2005, September). A typology of interactive whiteboard pedagogies. Paper presented at BERA Conference, UK, Wales, University of Glamorgan.

Somekh, B., Underwood, J., Convery, A., Dillon, G., Harber, T., Jarvis, S. J., ...Woodrow, D. (2006). Evaluation of the ICT test bed project annual report. Retrieved from http://www1.prometheanplanet.com/french/staged/upload/pdf/Evaluation of the ICT Test Bed_Proj ect_2006.pdf

Somekh, B., Underwood, J., Convery, A., Dillon, G., Lewin, C., Mavers, D., ... Woodrow, D. (2005). Evaluation of the DfES ICT test bed project, annual report. Manchester, UK: Manchester Metropolitan University, Education \& Social Research Institute.

Swan, K., Schenker, J., \& Kratcoski, A. (2008).The effects of the use of interactive whiteboards on student achievement. Proceedings of World Conference on Educational Multimedia, Hypermedia and Telecommunications 2008 (pp. 3290-3297). Chesapeake, VA: AACE.

Thompson, J., \& Flecknoe, M. (2003). Raising attainment with an interactive whiteboard in Key Stage 2. Management in Education, 17(3), 29-33.

Underwood, J. D. M., Somekh. B., Cooke, A., Dillon, G., Lewin, C., Mavers. D., ... Saxon. D. (2004). Evaluation of the DfES ICT test bed project: First annual report 2003. Coventry, UK: BECTA. Retrieved from http://www.evaluation.icttestbed.org.uk

Walker, D. (2003). Quality at the dockside. TES Online, 3, 66-67.

Wallace, A. (2007, May 24). Do IWBs have a future in the UK classroom? Presentation at: Promethean/Futurelab debate, London, UK.

Way. J., Lifley, E., Ruster, C., Johnco, S., Mauric, L., \& Ochs, L. (2009). Symposium: Interactive whiteboards and pedagogy in primary classrooms. Paper presented at the Annual Conference of Australian Association for Research in Education, Canberra, Australia.

Wenglinsky, H. (2002). How school matters: The link between teacher classroom practices and student academic performance. Educational policy Analysis Archives, 10(12), Retrieved from http://epaa.asu.edu/epaa/v10n12/ 
Wood, R., \& Ashfield, J. (2008). The use of the interactive whiteboard for creative teaching and learning in literacy and mathematics: A case study. British Journal of Educational Technology, 39(1), 84-96

Zittle, F. (2004). Enhancing native American mathematics learning: The use of Smartboard generated virtual manipulatives for conceptual understanding. Retrieved from http://education.smarttech.com

\section{Biographies}

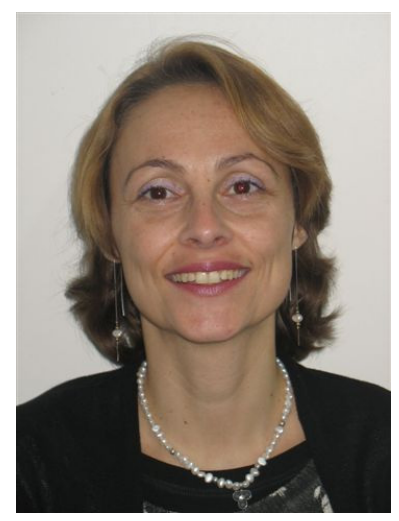

Dr. Edith Manny-Ikan is a senior researcher in the Henrietta Szold institute - the national institute for research in the behavioral sciences in Israel. Her research interests focus on evaluating ICT programs and their effects on students' attitudes and achievements, teachers perceptions about their changing professional role, schools change in ICT orientation and different effects of ICT on parents and the community. Dr. Manny-Ikan obtained her Ph.D. degree from the Faculty of Science Education at the Hebrew University in Jerusalem, Israel. She has written learning materials for high school and had also been a classroom teacher on Biology at the elementary, middle and high school levels

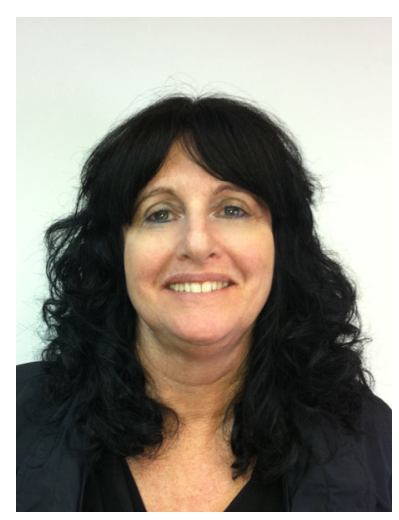

Dr. Osnat Dagan is the Pedagogical Manager at World ORT, an educational organization that has worked for over 130 years in over 60 countries. Dr. Dagan's academic and professional interests are: enhancing design and technology, the use of innovative pedagogy with ICT technology, and the development of both thinking and problem solving skills in constructivist methods. Dr. Osnat Dagan received her $\mathrm{PhD}$. from the School of Education at Tel-Aviv University in Israel. Her $\mathrm{PhD}$ focused on problem solving in design and technology for Junior High School students. After 20 years of teaching she worked to develop new curriculum materials for science and technology education. Dr. Dagan has worked in World ORT, London as the Research \& Development coordinator and returned to Israel as a Technology Teacher Center manager at the Technion Institute in Haifa.

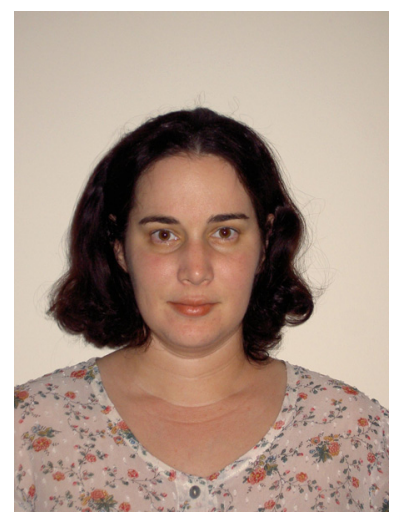

Tal Berger- Tikochinski is a research assistant in the Henrietta Szold institute - the national institute for research in the behavioral sciences in Israel. Her research interests focus on evaluating ICT programs assimilating various technologies in schools and their effects on students' and teachers' attitudes and perceptions. Mrs. Berger-Tikochinski has an M.A in Sociology of Education from the Hebrew University in Jerusalem, Israel. 


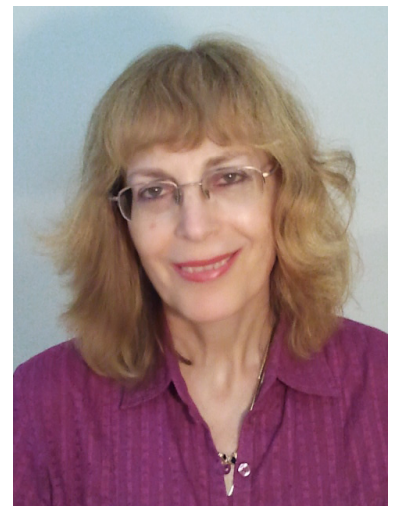

Dr. Rachel Zorman is the executive director of the Henrietta Szold Institute, the National Institute for Research in the Behavioral Sciences, in Jerusalem, Israel. The Szold Institute is dedicated to serve the Israeli education system from 1941 by providing research and evaluation services that focus on major issues, such as evaluating yearly progress toward program goals and objectives and providing data-based feedback to enhance program accountability. Dr. Rachel Zorman has extensive experience in managing teams of professionals conducting formative and summative evaluations of educational programs and initiatives promoting educational equity and creating opportunities for students from diverse backgrounds to close the achievement gap. These include programs promoting technology knowledge and skills in various contexts. 